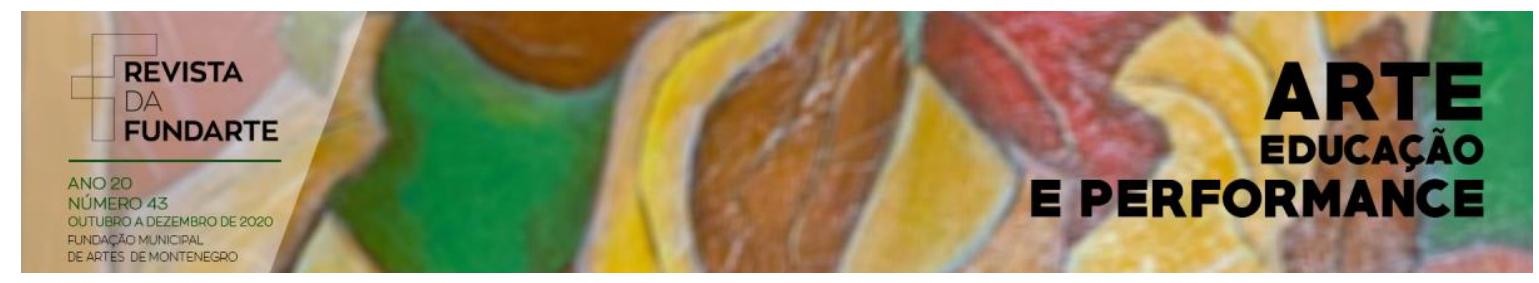

\title{
QUE TRAGÉDIA É ESSA? \\ Contextualizando Tragédias Gregas no Ensino de Teatro na EJA
}

Márcio Silveira dos Santos

DOI: http://dx.doi.org/10.19179/2F2319-0868/2F737

SANTOS, Márcio Silveira dos. Que tragédia é essa? Contextualizando Tragédias Gregas no Ensino de Teatro na EJA. Revista da FUNDARTE. Montenegro, p.01-20, ano 20, no 43, outubro/dezembro de 2020.

Disponível em: http://.seer.fundarte.rs.gov.br/index.php/revistadafundarte/index> 20 de dezembro de 2020. 


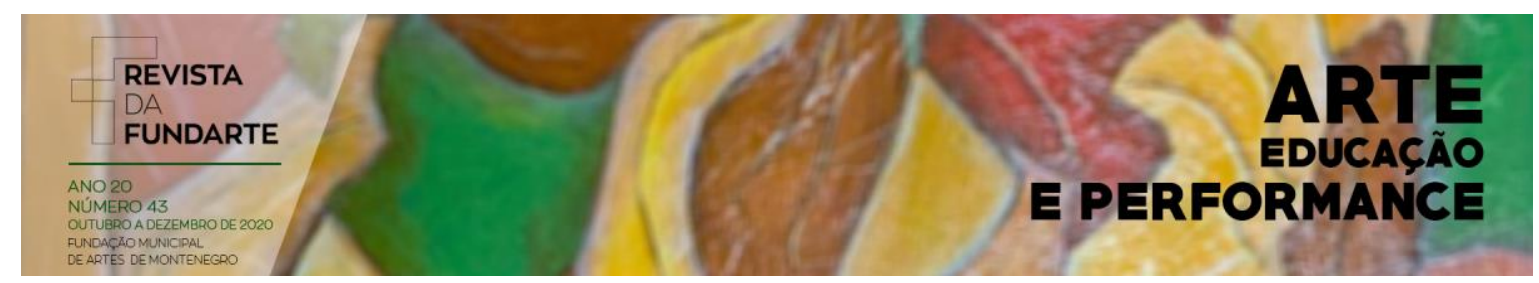

\section{QUE TRAGÉDIA É ESSA? \\ Contextualizando Tragédias Gregas no Ensino de Teatro na EJA}

Márcio Silveira dos Santos ${ }^{1}$

Resumo: O presente artigo traz reflexões sobre práticas do ensino de teatro na modalidade EJA Educação de Jovens e Adultos, tendo como base dramaturgias de Sófocles e as teorias de Augusto Boal, Paulo Freire, Eric Bentley e Martin Esslin. As práticas em sala de aula foram desenvolvidas durante dois trimestres com discentes de uma escola pública do Vale dos Sinos, no Rio Grande do Sul, cuja ênfase se deu na contextualização de tragédias gregas, por meio das atividades de leitura, produção de escrita e encenações teatrais.

Palavras-chave: Educação de Jovens e Adultos; Ensino de teatro; Tragédias.

\section{WHAT TRAGEDY IS THAT? Contextualizing Greek Tragedies in Theater Teaching at EJA}

Abstract: This article brings reflections on theater teaching practices in the EJA - Youth and Adult Education modality, based on Sophocles' dramaturgies and the theories of Augusto Boal, Paulo Freire, Eric Bentley and Martin Esslin. The classroom practices were developed during two quarters with students from a public school in Vale dos Sinos, Rio Grande do Sul, whose emphasis was on the contextualization of Greek tragedies through reading activities, writing production and staging theatrical.

Keywords: Youth and Adult Education; Theater teaching; Tragedies.

\footnotetext{
${ }^{1}$ Márcio Silveira dos Santos nasceu em Porto Alegre, no Estado do Rio Grande do Sul. É professorpesquisador com Licenciatura em Educação Artística - Habilitação em Artes Cênicas pelo Departamento de Arte Dramática da Universidade Federal do Rio Grande do Sul. Tem especialização em Psicopedagogia pela Universidade Castelo Branco e Mestrado em Artes Cênicas pelo Programa de Pós-Graduação em Artes Cênicas da Universidade Federal do Rio Grande do Sul. Atualmente é Doutorando no Programa de Pós-Graduação em Teatro da UDESC - Universidade do Estado de Santa Catarina (bolsista CAPES DS - Demanda Social). Também desempenha as funções de ator, diretor, produtor, músico, dramaturgo e palhaço no Grupo Manjericão (RS). É artista-articulador da RBTR - Rede Brasileira de Teatro de Rua e membro do GT Artes Cênicas na Rua da ABRACE Associação Brasileira de Pesquisa e Pós-Graduação em Artes Cênicas. De 2010 a 2014 foi representante da sociedade civil, por dois mandatos, no Colegiado Setorial de Teatro e no CNPC Conselho Nacional de Política Cultural do MINC - Ministério da Cultura (DF). É autor dos livros Longa Jornada de Teatro de Rua Brasil Afora (2016); Um Artista de Rua faz mais que um Ministro da Cultura (2018), livros editados pela UEBA Editora.
}

SANTOS, Márcio Silveira dos. Que tragédia é essa? Contextualizando Tragédias Gregas no Ensino de Teatro na EJA. Revista da FUNDARTE. Montenegro, p.01-20, ano 20, oㅡ 43, outubro/dezembro de 2020.

Disponível em: http://.seer.fundarte.rs.gov.br/index.php/revistadafundarte/index> 20 de dezembro de 2020. 


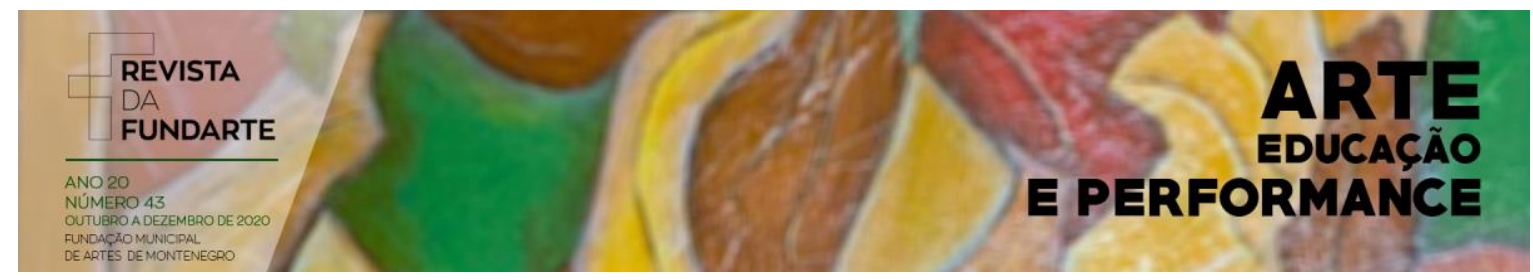

\section{Introdução}

No presente artigo procuro refletir acerca de um trabalho desenvolvido durante dois trimestres nas aulas de teatro com turmas da EJA - Educação de Jovens e Adultos - na Escola Municipal Arthur Ostermann, no Bairro Feitoria, do Município de São Leopoldo, no Rio Grande do Sul.

As atividades foram realizadas através de leituras, reescritas e encenações de tragédias gregas e suas contextualizações, visando o desenvolvimento dos potenciais criativos e a produção de uma reflexão crítica na sociedade. $O$ trabalho teve como estofo teórico e reflexivo nas áreas do teatro e educação, as obras de Augusto Boal e Paulo Freire; e na área dos estudos do texto teatral autores como Eric Bentley e Martin Esslin.

Mas antes de entrarmos nas práticas de sala de aula, se faz necessário explanar um pouco sobre a trajetória da Educação de Jovens e Adultos no país e no município onde as atividades foram realizadas, bem como a inserção do ensino de teatro neste contexto abordado.

\section{A EJA e o Teatro na EJA}

No início do século XX a pressão para acabar com o analfabetismo começou na área industrial, carente de mão-de-obra especializada. Diversos projetos oficiais surgiram, mas foram os movimentos sociais, com mais ênfase a partir dos anos 1950, que deram uma base maior para a Educação de Jovens e Adultos que temos no país hoje. A Ditadura Militar tentou acabar com iniciativas de educação e cultura popular como os Centros Populares de Cultura (CPC) e o Movimento de Educação de Base (MEB), entre outros, criando o Movimento Brasileiro de Alfabetização (MOBRAL) por meio do decreto nํㅜ 62. 455 de 1968, que foi extinto em 1985.

SANTOS, Márcio Silveira dos. Que tragédia é essa? Contextualizando Tragédias Gregas no Ensino de Teatro na EJA. Revista da FUNDARTE. Montenegro, p.01-20, ano 20, no 43, outubro/dezembro de 2020.

Disponível em: http://.seer.fundarte.rs.gov.br/index.php/revistadafundarte/index> 20 de dezembro de 2020. 


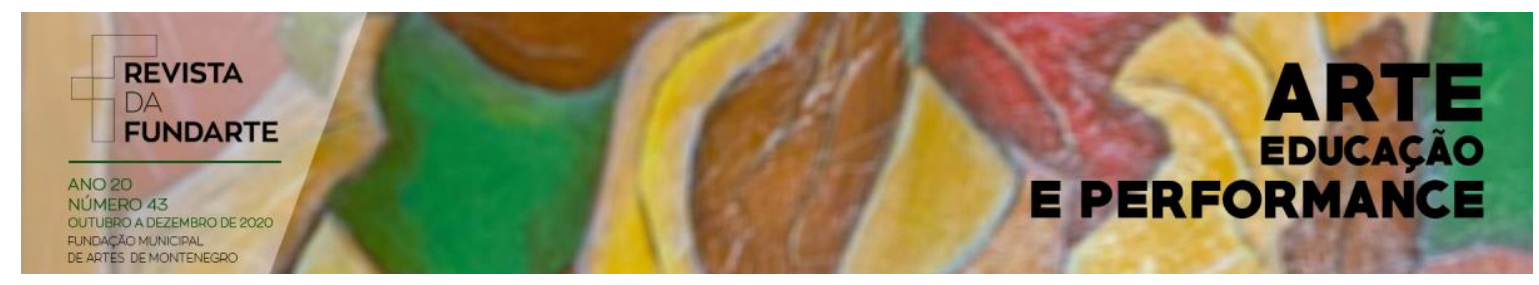

Com a Abertura Política, que culminou no ano de 1988 com a promulgação da nova Constituição Brasileira, a sociedade voltou a se organizar e no Brasil, participou de conferências internacionais, reforçando o compromisso com o fim do analfabetismo. O que colaborou para que, no ano de 1996, a LDB - Lei de Diretrizes e Bases da Educação Nacional, n 9.394/96, toda uma seção fosse dedicada à modalidade de ensino EJA, prevendo garantias de oferta na educação básica, como se verifica no artigo $4^{\circ}$, inciso VII:

VII - oferta de educação escolar regular para jovens e adultos, com características e modalidades adequadas às suas necessidades e disponibilidades, garantindo-se aos que forem trabalhadores as condições de acesso e permanência na escola. (LDB da Educação Nacional, no 9.394/96, artigo 4º , inciso VII, 1996).

A partir da LDB, n 9.394/96, foram formatadas as Diretrizes Curriculares Nacionais ${ }^{2}$, que definiram os objetivos da EJA, como "restaurar o direito à educação, negado aos jovens e adultos, oferecer a eles igualdade de oportunidades para a entrada e permanência no mercado de trabalho e qualificação para uma educação permanente" (LDB, nº 9.394/96).

Mas garantir este direito e igualdade de oportunidades não era o suficiente, pois ao atrair o adulto para a escola era preciso garantir também que ele não a abandonasse. Assim, as instâncias governamentais devem criar alternativas para o cumprimento da LDB, como garante o Artigo 5ํ no seu parágrafo 5ํ, "Para garantir o cumprimento da obrigatoriedade de ensino, o Poder Público criará formas

\footnotetext{
${ }^{2}$ As Diretrizes Curriculares Nacionais são um conjunto de normas e procedimentos obrigatórios para a Educação Básica, com base nos princípios presentes na Constituição, que orientam o planejamento escolar da instituição de ensino e o seu sistema de ensino auxiliando na organização, articulação e avaliação de suas propostas pedagógicas. Essas Diretrizes foram discutidas, elaboradas e determinadas pelo CNE - Conselho Nacional de Educação. Elas também afirmam ser responsabilidade da União estabelecer em colaboração com os Estados, Distrito Federal e os Municípios, competências e diretrizes para a educação infantil, o ensino fundamental e o ensino médio, que nortearão os currículos e os seus conteúdos mínimos, de modo a assegurar a formação básica comum.
}

SANTOS, Márcio Silveira dos. Que tragédia é essa? Contextualizando Tragédias Gregas no Ensino de Teatro na EJA. Revista da FUNDARTE. Montenegro, p.01-20, ano 20, oㅡ 43, outubro/dezembro de 2020.

Disponível em: http://.seer.fundarte.rs.gov.br/index.php/revistadafundarte/index> 20 de dezembro de 2020. 


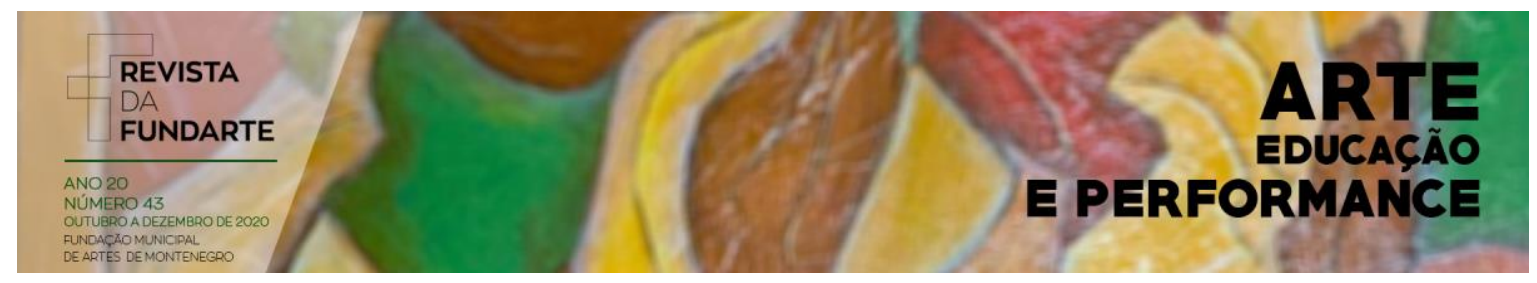

alternativas de acesso aos diferentes níveis de ensino, independentemente, da escolarização anterior" (2005, p. 09).

As altas taxas de evasão (menos de $30 \%$ concluem os cursos) tiveram origem no uso de material didático inadequado para a faixa etária, nos conteúdos sem significado, nas metodologias infantilizantes aplicadas por professores despreparados e em horários de aula que não respeitavam a rotina de quem estudava e trabalhava. Mesmo com problemas como esses, com o passar dos anos as questões mais nevrálgicas foram, aos poucos, sendo sanadas.

Nos últimos anos, houve um intenso movimento de jovens e adultos retornando à sala de aula. Quem não teve oportunidade de estudar na idade apropriada, ou que por algum motivo abandonou a escola antes de terminar a Educação Básica, está procurando as instituições de ensino para completar seus estudos. Aqueles que não sabem ler e escrever pretendem ser alfabetizados. Os que já têm essas habilidades desejam adquirir outros saberes e competências para que tenham novas chances no concorrido mercado de trabalho. Quando falo em mercado de trabalho, me refiro às normas internas de muitos empreendimentos que somente contratam pessoas que tenham completado, no mínimo, o ensino fundamental e/ou ensino médio. Assim, correndo o risco de ficarem sem emprego por muito tempo, os cidadãos retomam seus estudos, geralmente no período noturno, dentro da modalidade de ensino da Educação de Jovens e Adultos.

Segundo a LDB, a EJA - Educação de Jovens e Adultos visa proporcionar acesso à formação educacional dessa faixa etária, a partir dos 15 anos, tendo por objetivo cumprir de maneira satisfatória, a preparação dos jovens e adultos para o exercício da cidadania, bem como a qualificação profissional, junto ao mercado de trabalho e à sociedade. Sendo assim, e de acordo com os Parâmetros Curriculares Nacionais, para a concretização de uma prática administrativa e pedagógica, voltada de fato para o cidadão, é necessário que o processo de ensino-aprendizagem na EJA tenha coerência com as Diretrizes Curriculares Nacionais, como:

SANTOS, Márcio Silveira dos. Que tragédia é essa? Contextualizando Tragédias Gregas no Ensino de Teatro na EJA. Revista da FUNDARTE. Montenegro, p.01-20, ano 20, no 43, outubro/dezembro de 2020.

Disponível em: http://.seer.fundarte.rs.gov.br/index.php/revistadafundarte/index> 20 de dezembro de 2020. 


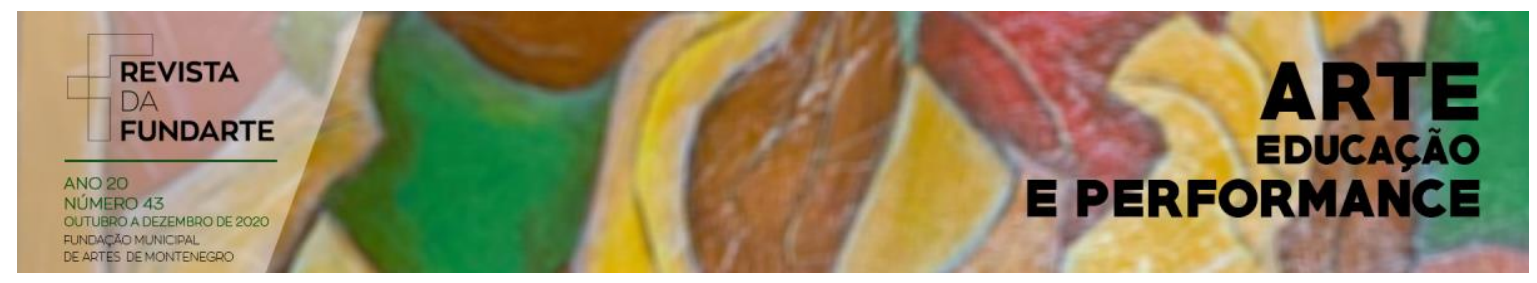

os princípios éticos de autonomia, da responsabilidade e do respeito ao bem comum;

os princípios políticos dos direitos e deveres de cidadania, do exercício da criticidade e do respeito à ordem democrática;

os princípios estéticos da sensibilidade, da criatividade e da diversidade de manifestações artísticas e culturais.

(RESOLUÇÃO CEB nº 2, 1998, p. 01).

Partindo dessas premissas, desenvolvi práticas de ensino de teatro com alunos e alunas de turmas de etapa II, que corresponde do $6^{\circ}$ ao $9^{\circ}$ ano do ensino fundamental, no ensino regular da educação básica brasileira. Aulas ocorridas no turno da noite da modalidade de ensino EJA - Educação de Jovens e Adultos, da Escola Municipal Arthur Ostermann localizada no bairro Feitoria no Município de São Leopoldo/RS ${ }^{3}$.

A inclusão da linguagem artística do teatro em 2006, no currículo da EJA, no Município de São Leopoldo, colaborou para a expansão de um trabalho voltado aos princípios de sensibilidade, criatividade e diversidade; para que com as práticas teatrais pudessem fortalecer $o$ potencial criativo dos alunos e alunas, proporcionando, dessa forma, que se ultrapassasse uma visão puramente instrumental da educação, considerada por alguns como uma via obrigatória para obter certos resultados (saber-fazer, aquisição de capacidades diversas, para fins de ordem econômica). E assim, a rede municipal de ensino passou a ampliar e qualificar o currículo, na modalidade Educação de Jovens e Adultos.

O Município de São Leopoldo contempla o Teatro em seus concursos para o magistério, em conformidade com a Lei no 9.394/96, onde no artigo 26, inciso 2, diz que o ensino de artes constituirá componente curricular obrigatório, nos diversos níveis da educação básica, de forma a promover o desenvolvimento cultural dos alunos. No conjunto de disciplinas de artes, compreendem-se as quatro linguagens artísticas: teatro, música, dança e artes visuais.

\footnotetext{
${ }^{3}$ A Cidade de São Leopoldo foi fundada em 25 de 1824 com a chegada dos primeiros imigrantes alemães. Fica localizada na Grande Porto Alegre a 31,4 km da capital gaúcha. Situada as margens do Rio dos Sinos a cidade é cortada pelas rodovias BR 101 e RS 240.

SANTOS, Márcio Silveira dos. Que tragédia é essa? Contextualizando Tragédias Gregas no Ensino de Teatro na EJA. Revista da FUNDARTE. Montenegro, p.01-20, ano 20, no 43, outubro/dezembro de 2020.

Disponível em: http://.seer.fundarte.rs.gov.br/index.php/revistadafundarte/index> 20 de dezembro de 2020.
} 


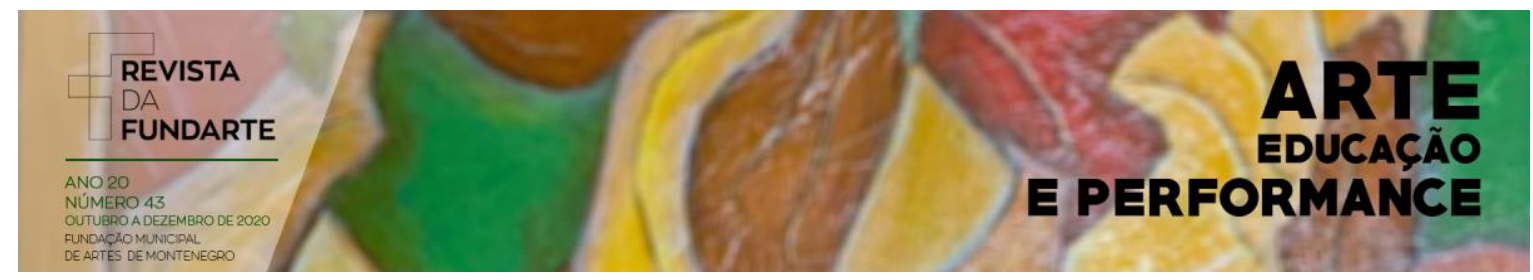

Na EJA há um ambiente diversificado, onde as práticas de ensino com o teatro se transformam numa via que, além de trazer novas propostas de aprendizagem e desenvolvimento do indivíduo, podem também esboçar novas diretrizes para as relações criadas e vividas no ambiente escolar, e que ecoam na vida cotidiana de cada um. Foi a partir desses fatores que procurei, durante este contexto escolar, uma proposta de abordagem dialética, dentro do eixo pedagógico do teatro e educação. O propósito desta converge com os estudos do pesquisador Dr. João Pedro Alcântara Gil que afirma:

A formação da sensibilidade humana é o caminho da pesquisa em educação e teatro numa perspectiva dialética marxiana. Não é o produto final, o resultado da análise última dos dados que importa. Não interessa a quantidade, mas o conjunto da práxis social. (GIL,P.A, 2004, p. 62).

Pensando nesse sensível do ser humano e suas relações sociais, econômicas, culturais e educacionais, dentro e fora do ambiente da educação formal, foi possível estabelecer questões que pudessem ser elucidadas durante as aulas práticas de teatro em sala de aula, ou seja, estabeleci questões como: Qual práxis de reflexão se constitui a partir do ensino de teatro na EJA? Qual a dramaturgia que se revela na produção escrita e teatral na EJA? Quais as imbricações emergem do conteúdo das aulas e o tecido social no qual o aluno vive? Como se constituem as ações/cenas, a partir das vivências próprias de cada aluno? Em que medida o teatro na EJA pode estimular na tomada de consciência e um olhar mais crítico?

$\mathrm{Na}$ Educação de Jovens e Adultos são criadas novas relações humanas, e no bojo dessa nova estrutura de convívio, o teatro surge como um veículo de aproximação, vivência e transformação dialética, seja no campo educacional como também no desenvolvimento sociocultural (VYGOSTSKY, 1987, 2002). Busquei neste espaço social uma proposta de autonomia, não só do aluno mas, principalmente, do homem em sua realidade (FREIRE, 1970, 1993). Há uma troca

SANTOS, Márcio Silveira dos. Que tragédia é essa? Contextualizando Tragédias Gregas no Ensino de Teatro na EJA. Revista da FUNDARTE. Montenegro, p.01-20, ano 20, no 43, outubro/dezembro de 2020.

Disponível em: http://.seer.fundarte.rs.gov.br/index.php/revistadafundarte/index> 20 de dezembro de 2020. 


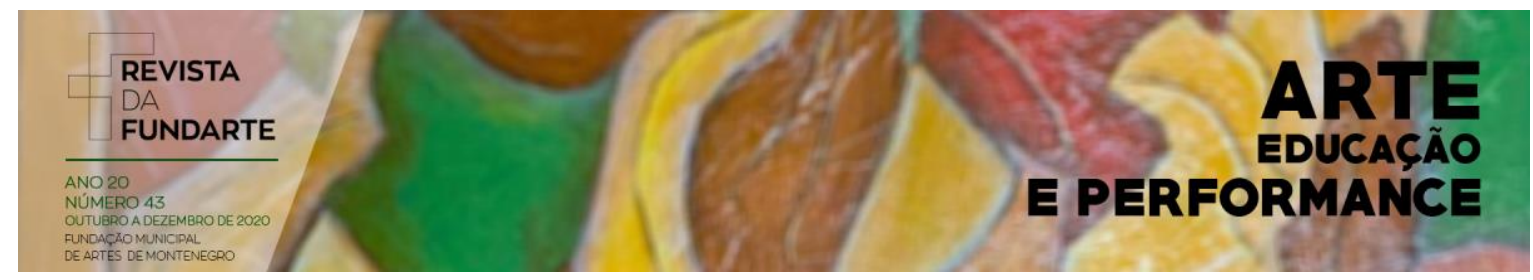

de ideias e conhecimentos entre o que se sabe e o que se descobre com os demais, numa troca contínua de saberes e práticas com boa desenvoltura. Há a evolução de uma consciência crítica relativa aos fatos da sociedade em que estão inseridos.

Neste sentido, no início das atividades, procurei traçar um paralelo comparativo com o que se conhece e o que se descobre. Por meio de uma prévia da sala de aula, com as práticas teatrais, através da leitura de peças, como as tragédias gregas, a reescrita contextualizando as peças, e a construção e apresentação de cenas, debates e discussões, o grupo de alunos se organiza (BOAL, 1975, 1979, 1980, 2002), se estruturando conforme a necessidade e o conhecimento que apresenta.

Assim, a atividade que escolhi, como recorte apresentado aqui, foi o processo de contextualização de duas dramaturgias gregas: Édipo Rei e Antígona. A seguir procuro discorrer sobre, pontuando suas fundamentações para, em seguida, relatar e refletir sobre os meios e os fins deste rico processo.

\section{A produção textual na EJA por meio de dramaturgias}

A proposta de práticas de sala de aula que propus estava contemplada nos PCNs e na norma do Programa de implantação da modalidade EJA, em São Leopoldo, que preconizava a realização de produção textual em turmas da etapa II. Em todas as disciplinas, em algum momento do currículo de ensino, deveriam trabalhar com a escrita. Em teatro, fui para o caminho da escrita do texto teatral, a dramaturgia. A proposta inicial consistia na leitura de textos teatrais, e fui incentivando os alunos a pesquisaram publicações, dentro e fora do ambiente escolar. Alguns foram à biblioteca da escola e retiraram todos os livros de texto para teatro, que na sua maioria eram peças infanto-juvenis. Também encontraram dois livros contendo tragédias gregas, Antígona e Édipo Rei, de Sófocles ${ }^{4}$. Solicitei que

\footnotetext{
${ }^{4}$ Sófocles foi um importante dramaturgo da Grécia Antiga. Nasceu na cidade-estado de Atenas em 496 a.C. e morreu em 406 d.C. É considerado um dos grandes representantes do teatro grego antigo, junto com Eurípedes e Ésquilo. Viveu no período de maior desenvolvimento cultural de Atenas.
}

SANTOS, Márcio Silveira dos. Que tragédia é essa? Contextualizando Tragédias Gregas no Ensino de Teatro na EJA. Revista da FUNDARTE. Montenegro, p.01-20, ano 20, no 43, outubro/dezembro de 2020.

Disponível em: http://.seer.fundarte.rs.gov.br/index.php/revistadafundarte/index> 20 de dezembro de 2020. 


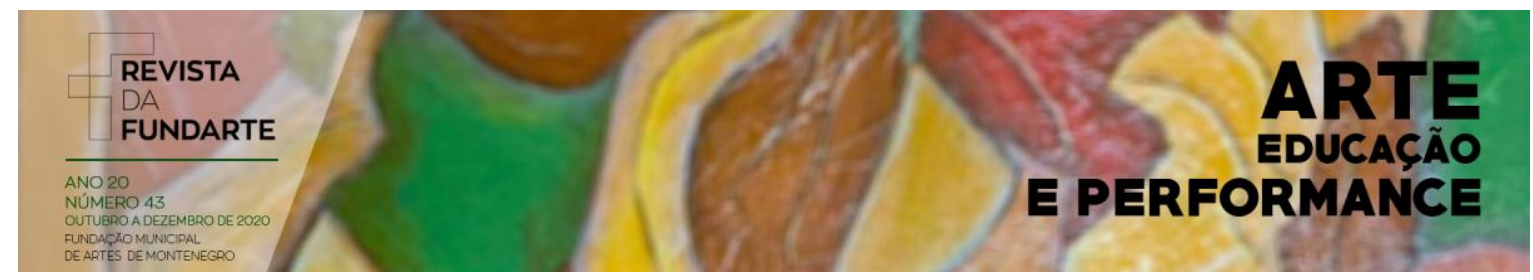

cada um fizesse uma leitura de uma das duas tragédias e em seguida, realizassem uma sinopse do texto lido.

Dividi a turma em grupos de três alunos e feitas as sínteses dos textos, iniciaram suas leituras. Após cada grupo realizar as suas leituras, debatíamos e indagávamos sobre a concisão da história e o que era importante realmente constar nesta sinopse, para que o leitor/aluno/espectador entendesse sobre o assunto principal da peça, suas tramas e subtramas, personagens, contexto, sua estrutura e desenvolvimento (início, meio e fim), como por exemplo, quais eram os personagens principais? Quem protagonizava? Quem eram os coadjuvantes? Qual sua evolução na trama? Qual a temática central? Quais os conflitos de cada personagem e as soluções que o dramaturgo utilizou para o desfecho final? Estudamos também a estrutura de escrita do texto teatral e suas diferenças para com o romance, o conto, os quadrinhos, o cinema e a poesia.

Procurei, também, ir introduzindo os alunos na prática da escrita do texto teatral, que seria a próxima etapa. Aos poucos explanava sobre a estrutura do texto clássico para teatro, na forma de diálogos, as relações de tempo e espaço, e as estratégias que o dramaturgo utiliza para se inserir nesta escrita dramática. A forma mais comum de participação do dramaturgo no texto se dá através das didascálias. Segundo Pavis (2003, p. 96), "do grego didascalia, ensinamento. São instruções dadas pelo autor aos seus atores (teatro grego, por exemplo), para interpretar o texto teatral". Por extensão, na forma mais moderna, são conhecidas como: indicações cênicas ou rubricas.

Vamos às duas tragédias gregas.

\section{Édipo Rei, de Sófocles.}

\footnotetext{
$\mathrm{Na}$ história grega, Laio, o rei de Tebas havia sido alertado pelo Oráculo de Delfos que uma maldição iria se concretizar: seu próprio filho o mataria e que este filho se casaria com a própria mãe. Por tal motivo, ao nascer Édipo, Laio abandonou-o no monte Citerão pregando um prego em cada pé para tentar matá-lo. O menino foi
}

SANTOS, Márcio Silveira dos. Que tragédia é essa? Contextualizando Tragédias Gregas no Ensino de Teatro na EJA. Revista da FUNDARTE. Montenegro, p.01-20, ano 20, no 43, outubro/dezembro de 2020.

Disponível em: http://.seer.fundarte.rs.gov.br/index.php/revistadafundarte/index> 20 de dezembro de 2020. 


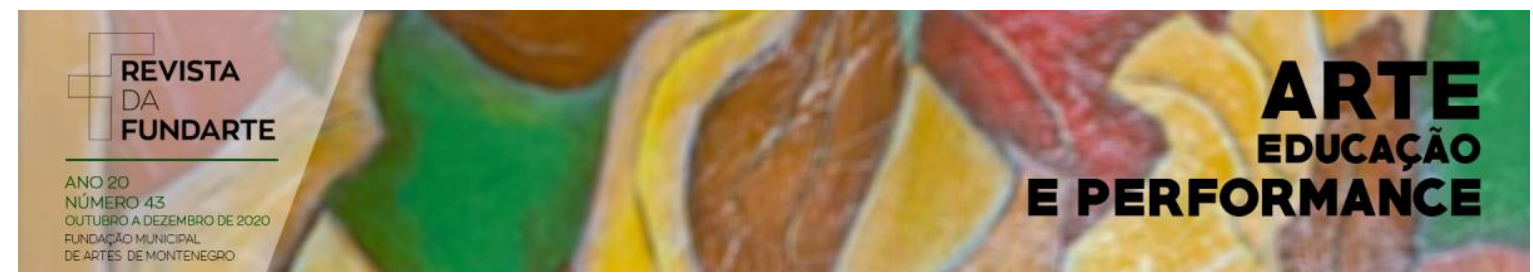

recolhido mais tarde por um pastor e batizado como "Edipodos", o de "pés-furados", que foi adotado depois pelo rei de Corinto e voltou a Delfos. Édipo consulta o Oráculo que lhe dá a mesma previsão dada a Laio, que mataria seu pai e desposaria sua mãe. Achando se tratar de seus pais adotivos, foge de Corinto. No caminho, Édipo encontrou um homem e, sem saber que era o seu pai, brigou com ele e o matou, pois Laio o mandou sair de sua frente. Após derrotar a Esfinge que aterrorizava Tebas, que lançara um desafio ("Qual é o animal que tem quatro patas de manhã, duas ao meio-dia e três à noite?"), Édipo conseguiu desvendar, dizendo que era o homem. "O amanhecer é a criança engatinhando, entardecer é a fase adulta, que usamos ambas as pernas, e o anoitecer é a velhice quando se usa a bengala". Conseguindo derrotar o monstro, ele seguiu à sua cidade natural $\mathrm{e}$ casou-se, "por acaso", (já que ele pensava que aqueles que o haviam criado eram seus pais biológicos) com sua mãe, com quem teve quatro filhos. Quando da consulta do oráculo, por ocasião de uma peste, Jocasta e Édipo descobrem que são mãe e filho, ela comete suicídio e ele fura os próprios olhos por ter estado cego e não ter reconhecido a própria mãe. Após sair do palácio, Édipo é avisado pelo Corifeu que não é mais rei de Tebas; Creonte ocupara o trono, desde então. Édipo pede para ser exilado, mandado embora. Pede, ainda, para que Creonte cuide de seus filhos, Antígona, Ismênia, Etéocles e Poliníces, como se fossem seus próprios. (BRANDÃO, 1985, p. 39)

\section{Antígona, de Sófocles.}

Conta a historia de Antígona, que deseja enterrar seu irmão Polinices, que atentou contra a cidade de Tebas, mas o tirano da cidade, Creonte, promulgou uma lei impedindo que os mortos que atentaram contra a lei da cidade fossem enterrados, o que era uma grande ofensa para o morto e sua família, pois a alma do morto não faria a transição adequada ao mundo dos mortos. Antígona, enfurecida, vai então sozinha contra a lei de uma cidade e enterra o irmão, desafiando a tudo e todos, Antígona é então capturada e levada até Creonte, que sentencia Antígona à morte, não adiantando nem os apelos de Hemon, filho de Creonte e noivo de Antígona, que clama ao pai pelo bom senso e pela vida de Antígona, pois ela apenas queria dar um enterro justo ao irmão. Hemon briga com Creonte e Antígona é levada a morte, uma tumba onde Antígona ficará até morrer. Aparece Tirésias, o adivinho, que avisa a Creonte que sua sorte está acabando, pois o orgulho em não enterrar Polinices acabará destruindo seu governo. Antes de poder fazer algo, Creonte descobre que Hemon, seu filho, se matou, desgostoso com a pena de morte de Antígona. Aparece Eurídice e conta que, ao abrir a tumba onde Antígona estava presa, encontram-na enforcada. Eurídice,

SANTOS, Márcio Silveira dos. Que tragédia é essa? Contextualizando Tragédias Gregas no Ensino de Teatro na EJA. Revista da FUNDARTE. Montenegro, p.01-20, ano 20, oㅡ 43, outubro/dezembro de 2020.

Disponível em: http://.seer.fundarte.rs.gov.br/index.php/revistadafundarte/index> 20 de dezembro de 2020. 


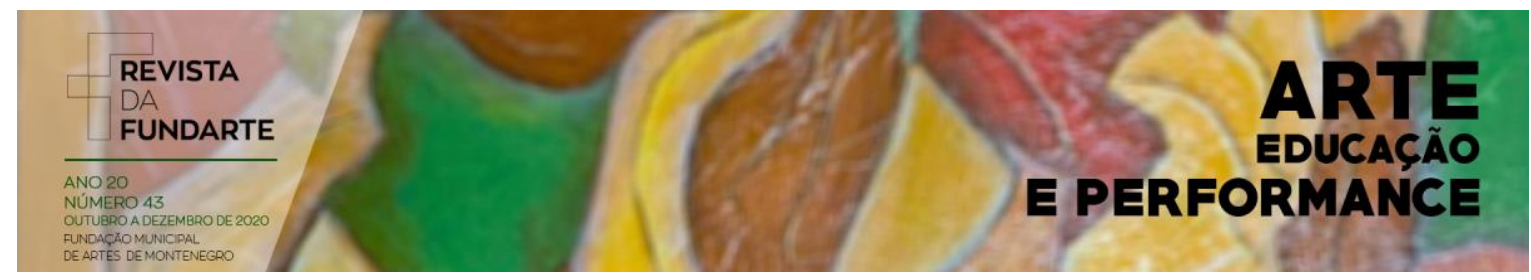

desiludida pela morte do filho também se mata, para desespero de Creonte, que ao ver toda sua família morta se lamenta por todos os seus atos, mas principalmente pelo ato de não ter atendido o desígnio dos deuses, o que the custou à vida de todos aqueles que lhe eram queridos. (BRANDÃO, 1985, p. 51).

Após leituras das sínteses dos alunos e a leitura que realizei destas duas sinopses aqui expostas, feitas pelo pesquisador Junito de Souza Brandão, os alunos levantaram uma dúvida que se tornou o ponto crucial para iniciar a contextualização destas duas tragédias gregas para os dias atuais, em consonância aos fatos vigentes na comunidade ou sociedade em geral.

Os alunos indagaram se aqueles textos eram retratos do período em que foram escritos, assim como os acontecimentos que a sociedade hoje chamaria de "tragédia!". Solicitei então aos alunos que realizassem uma pesquisa sobre as definições de tragédia e que trouxessem, também, aquilo que para eles seria tragédia, hoje em dia. No dicionário de teatro de Patrice Pavis, existem sete páginas dedicadas à tragédia e suas derivações; destaco uma definição:

\begin{abstract}
(Do grego tragoedya, canto do bode - sacrifício aos deuses pelos gregos). Peça que representa uma ação humana funesta muitas vezes terminada em morte. Aristóteles dá uma definição de tragédia que influenciará profundamente os dramaturgos até nossos dias: "A tragédia é a imitação de uma ação de caráter elevado e completo, de uma certa extensão, numa linguagem temperada com condimentos de uma espécie particular conforme as diversas partes, imitação que é feita por personagens em ação e não por meio de narrativa, e que, provocando piedade e temor, opera a purgação própria de semelhantes emoções". (PAVIS, 2003, p. 415).
\end{abstract}

Também explanei aos alunos alguns dos elementos que compõem a tragédia grega. Mesmo que não memorizassem tais terminologias, entenderiam o significado que Pavis coloca de forma compreensível a estudantes no assunto.

Vários elementos fundamentais caracterizam a obra trágica: a catharsis ou a purgação das paixões pela produção do terror e da

SANTOS, Márcio Silveira dos. Que tragédia é essa? Contextualizando Tragédias Gregas no Ensino de Teatro na EJA. Revista da FUNDARTE. Montenegro, p.01-20, ano 20, no 43, outubro/dezembro de 2020.

Disponível em: http://.seer.fundarte.rs.gov.br/index.php/revistadafundarte/index> 20 de dezembro de 2020. 


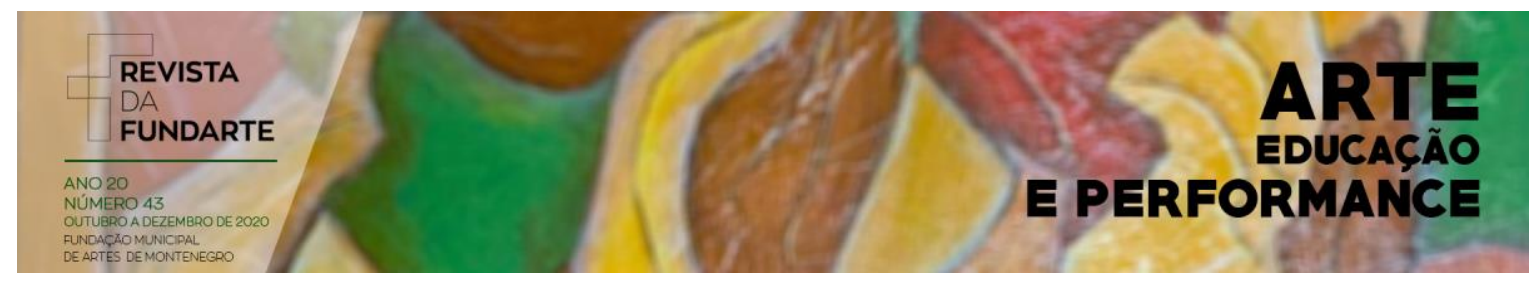

piedade; a hamartia ou ato do herói que põe em movimento o processo que o conduzirá à perda; a hybris, orgulho e teimosia do herói que persevera apesar das advertências e recusa esquivar-se; o pathos, sofrimento do herói que a tragédia comunica ao público. Uma sequencia tipicamente trágica teria por "fórmula mínima": o mythos é a mimese da práxis através do pathos até a anagnoris. (PAVIS, 2003, p 416).

O que significa, dito de maneira clara: a história trágica imita as ações humanas colocadas sob o signo dos sofrimentos das personagens e da piedade, até o momento, do reconhecimento das personagens entre si, ou da conscientização da fonte do mal. A partir da compreensão destes elementos fundamentais na construção de uma boa trama de um texto trágico, os alunos partiram para criação de suas próprias peças. O objetivo era que construíssem textos que contextualizassem nos dias de hoje, os personagens, enredos, tramas das peças e mitos gregos de que tivessem conhecimento. Poderiam ir além dos textos encontrados na biblioteca da escola, bem como materiais de revistas e pesquisas na internet.

Porém, antes de iniciarem as escritas, levei uma máscara semelhante a da tragédia grega e propus um exercício prático com a sua utilização. Dividimos a sala em forma de palco/plateia. Na área do palco duas cadeiras, uma delas com a máscara à espera de alguém para colocá-la. Duas pessoas se dirigiram para as cadeiras e uma colocava a máscara. Aquela que colocava, seria o personagem trágico, que criaria de improviso uma movimentação carregada de sentimentos trágicos. Um exercício livre, sem qualquer impedimento dos sentimentos que surgissem espontaneamente. Bastava expressar um sentimento trágico, que a outra pessoa se encarregaria de criar uma reação, que culminasse num desfecho da movimentação das duas pessoas.

Uma cena que destaco, foi quando uma aluna pegou a máscara e realizou o movimento de desolação por perda de alguém. Lamentava, como Creonte diante do filho morto, ou como Antígona diante do irmão insepulcro Polinices. Imediatamente, a outra pessoa se pôs como o corpo do outro personagem trágico, esticando-se com

SANTOS, Márcio Silveira dos. Que tragédia é essa? Contextualizando Tragédias Gregas no Ensino de Teatro na EJA. Revista da FUNDARTE. Montenegro, p.01-20, ano 20, no 43, outubro/dezembro de 2020.

Disponível em: http://.seer.fundarte.rs.gov.br/index.php/revistadafundarte/index> 20 de dezembro de 2020. 


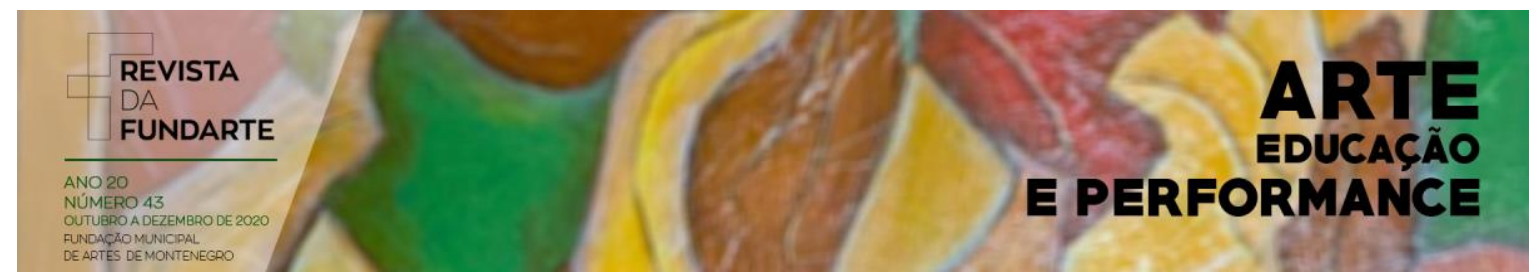

as mãos crispadas para o outro, e caindo lentamente até o chão. Passou-lhe a mão no rosto e deu um último adeus, antes de cobrir-lhe com um casaco. Uma cena extremamente poética e densa para aqueles alunos que tiveram um primeiro contato com uma máscara de tragédia e com os textos gregos.

Após os exercícios com a máscara, analisamos as cenas, e explanei sobre os processos da escrita de textos para teatro e da potência que pode ser essa escrita, como um veículo da consciência crítica do homem, em relação aos fatos vigentes no mundo. A partir deste momento, iniciaram a prática da escrita dramática, através de princípios básicos do drama, como a estrutura, o enredo, a trama, os conflitos, os personagens, a construção de cenas, os nós dramáticos e o clímax. Elementos básicos para uma eficiente dramaturgia, como nos esclarece Eric Bentley sobre as tragédias.

\begin{abstract}
A peça deveria ser uma catástrofe motivada pelos personagens e situações; sua exposição e diálogos devem ser geralmente analíticos, isto é, devem carregar a ação e informar-nos dos fatos preliminares ao mesmo tempo; a trama ideal é simples, na qual, não muitas pessoas, contrastantes em motivações e temperamentos, são juntadas no menor espaço possível. (BENTLEY, 1991, p. 73).
\end{abstract}

Seguimos o trabalho, que durante algumas aulas os alunos desenvolveram textos curtos, cujas temáticas traição e vingança, mostraram a tônica. A dramaturgia foi criada, individualmente, ou em duplas, e não em grupos maiores como de costume, pois entre outras intenções, a ideia era produzir um banco de peças, para deixar na biblioteca da escola, para serem encenadas no ano seguinte, ou para outras turmas.

\title{
Que tragédia é essa?
}

Apresento aqui um pouco mais do trabalho com as tragédias, sob o enfoque da contextualização do bairro, e a realidade dos alunos e comunidade. Trabalhamos a contextualização das tragédias gregas aos fatos do mundo contemporâneo, nas

SANTOS, Márcio Silveira dos. Que tragédia é essa? Contextualizando Tragédias Gregas no Ensino de Teatro na EJA. Revista da FUNDARTE. Montenegro, p.01-20, ano 20, no 43, outubro/dezembro de 2020.

Disponível em: http://.seer.fundarte.rs.gov.br/index.php/revistadafundarte/index> 20 de dezembro de 2020. 


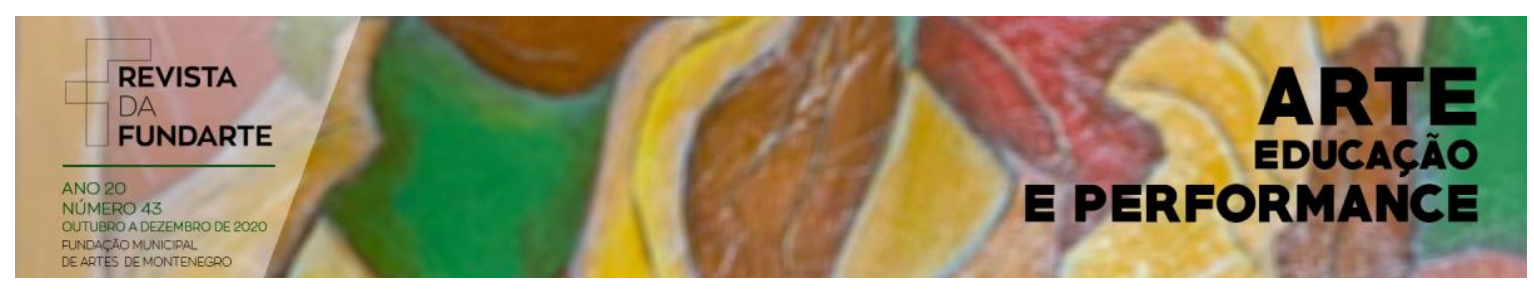

práticas de sala de aula de uma etapa II da EJA, na Escola Municipal Arthur Ostermann. Busquei desenvolver um processo de transformação sociocultural de um determinado grupo de alunos. Ao estudar as tragédias, percebi que o contexto social do bairro da escola era de uma violência muito grande, recheado de sérias tragédias pessoais e coletivas, semelhantes a alguns temas abordados pela dramaturgia grega, como vingança, morte, parricídio e guerra de poderes. Então, em conjunto com os alunos, fizemos a seguinte indagação: Que tragédia é essa?

Partimos para uma proposta de contextualização dos mitos gregos, tendo como base as peças das tragédias gregas, e que hoje estariam presentes em nossa sociedade. Então iniciamos a busca por respostas, com leituras de Édipo Rei e Antígona, de Sófocles, bem como assistimos à filmes que tivessem alguma relação um pouco mais contemporânea, que contribuíssem para que depois os alunos encenassem. Em seguida, começamos uma sequência de aulas, voltadas para a escrita dramatúrgica, acrescidas de um jogo teatral como aquecimento e integração coletiva, e improvisação com máscara, procurando desenvolver a criatividade, visando descobrir as potencialidades e a fruição estética e, contribuindo para o aprendizado dos alunos e incentivo à cultura da região da escola.

Os fatos debatidos e que produziram reflexões, entre outros, foram aqueles que ocorreram durante o ano na comunidade da Feitoria, como o caso da mãe que durante uma enchente do Rio dos Sinos (às margens do qual a cidade foi fundada), ao perder tudo dentro de casa, teve que pernoitar em um albergue municipal e ao adormecer, descuidou dos dois filhos que juntos, adormeciam em uma cama de bebê. O filho mais novo, com apenas alguns meses de idade, amanheceu morto devido à asfixia, pois o irmão mais velho, de sete anos, dormindo, havia ficado por cima do irmão mais novo.

Também teve o caso de um parricídio seguido de prisão e morte. Reunimos estes fatos e mais alguns ocorridos pelo mundo, como o de um pai que manteve em cativeiro a filha por mais de 20 anos e teve com ela muitos filhos, no porão de sua casa, sem a mãe e esposa, sequer nunca ter desconfiado. Outro fato, foi o caso da

SANTOS, Márcio Silveira dos. Que tragédia é essa? Contextualizando Tragédias Gregas no Ensino de Teatro na EJA. Revista da FUNDARTE. Montenegro, p.01-20, ano 20, no 43, outubro/dezembro de 2020.

Disponível em: http://.seer.fundarte.rs.gov.br/index.php/revistadafundarte/index> 20 de dezembro de 2020. 


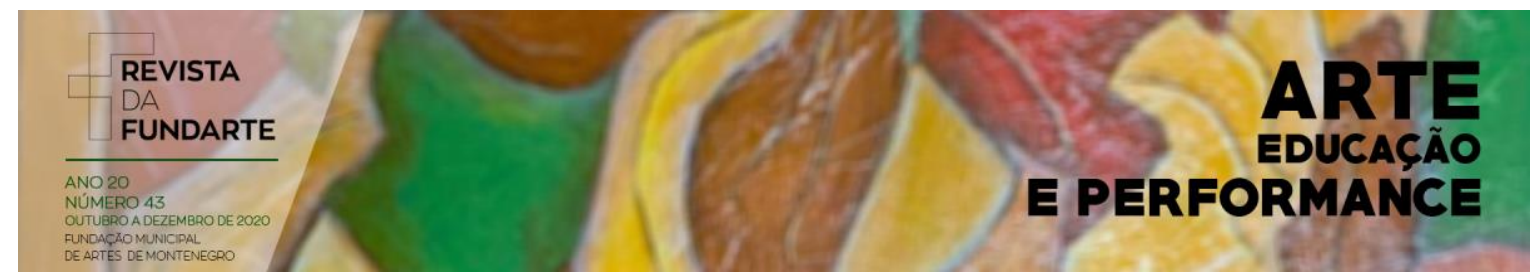

criança que tinha sido jogada do alto de um edifício, supostamente pelo pai e pela madrasta, caso que por muito tempo ficou sem solução. Depois partimos para os debates e encenações dos cruzamentos entre o passado e o presente, a ficção e a realidade.

Utilizamos alguns filmes que proporcionasse à turma uma ideia de contextualização de peças clássicas aos dias de hoje. Destaco os filmes Poderosa Afrodite (1995), de Woody Allen; e Romeu + Julieta (1996), de Baz Lurhmann.

Em Poderosa Afrodite vemos a história de um casal que adota uma criança, Max, que se revela muito inteligente. O pai adotivo fica obcecado com a procura dos pais biológicos de Max, para verificar se também devem ter uma inteligência acima da média. A história é entrelaçada com coros gregos, que ligam a narrativa do filme com a história de Édipo Rei, de Sófocles. Também serviu para mostrar como era um teatro grego original, já que o filme teve cenas filmadas num anfiteatro grego, na Itália.

O filme Romeu + Julieta, de Baz Lurhmann, é uma versão para os dias de hoje da peça de Shakespeare, cuja história se passa em Verona Beach. Os Capuletos e os Montéquios, duas famílias que sempre se odiaram, têm rixas sem cessar, mas isto não impede que Romeu, um Montéquio, se apaixone pela bela Julieta, uma Capuleto. Entretanto uma apresentadora de televisão anuncia que esse amor profundo acabará gerando trágicas consequenciais, em virtude desta insana rivalidade familiar. Utilizamos este filme como referência de atualização de um texto clássico, que mesmo não sendo uma tragédia grega, ainda sim a história de Romeu e Julieta, de Shakespeare, era citada constantemente pela turma, quando se falava de peça de teatro adorada por todos.

Além desses filmes utilizamos a máscara grega da tragédia, como já mencionado no subcapitulo anterior. Estes foram os principais recursos utilizados para a realização de uma contextualização potente e coerente com o contexto local. O universo cotidiano dos alunos, expandido para os contextos do mundo, retratados nas peças foram a base de tudo. O que para Martin Esslin é fundamental:

SANTOS, Márcio Silveira dos. Que tragédia é essa? Contextualizando Tragédias Gregas no Ensino de Teatro na EJA. Revista da FUNDARTE. Montenegro, p.01-20, ano 20, no 43, outubro/dezembro de 2020.

Disponível em: http://.seer.fundarte.rs.gov.br/index.php/revistadafundarte/index> 20 de dezembro de 2020. 


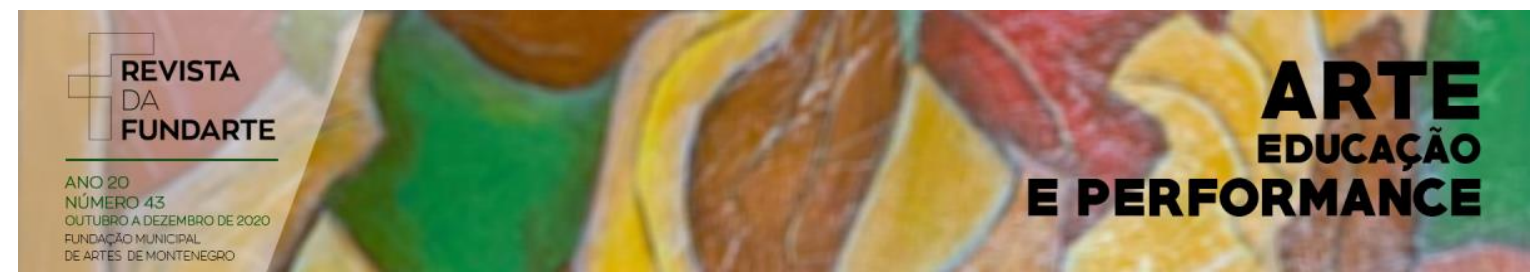

O contexto é tudo: inserido no contexto adequado, um gesto quase que imperceptível poderá mover montanhas, a mais simples das frases poderá transformar-se na mais sublime expressão poética... uma vez que a atenção e o interesse do espectador tenham sido captados, uma vez que ele tenha sido induzido a seguir a ação com total concentração e envolvimento, seus poderes de percepção estarão intensificados, suas emoções passarão a fluir livremente e ele atingirá, na verdade, um estado exacerbado de conscientização no qual ficará mais receptivo, mais observador, mais apto a discernir a unidade e o desenho geral da existência humana. (ESSLIN, 1978, p. 58-59).

Todos os pontos e questões levantados aqui foram fundamentais na ressignificação destes contextos. Acredito que propiciaram leituras e novas discussões sobre conceitos, pensamentos estéticos e filosóficos da arte, fundamentos histórico-culturais, extremamente, importantes para as vivências de todos, principalmente através do entendimento dos mitos gregos, pelas leituras das peças de teatro da dramaturgia grega. Particularmente, estudaram as diferentes expressões faciais presentes na máscara grega da tragédia, utilizada como forma de revelar sentimentos de dor, de horror e de ironia. Depois dessa atividade, os alunos tornaram-se capazes de observar e identificar os sentimentos retratados nas expressões faciais, das máscaras usadas na tragédia, bem como, na comédia grega e de perceber como essas expressões são utilizadas no mundo moderno. Ao encontro desta prática Esslin nos fala sobre o drama moderno e as aptidões em decifrar códigos do espectador:

O drama teatral moderno, seja no teatral seja no dos veículos de comunicação de massa, assume muito menos comprometimentos. À medida que as plateias dos veículos de massa são expostas a quantidades cada vez maiores de drama, é inevitável que seja elevado o nível de sofisticação: as pessoas tornam-se mais observadoras, mais aptas a decifrar os códigos de sugestões introduzidos aqui e ali, bem como se tornam mais céticas quanto à possibilidade de aceitar sem hesitação o que é dito ou feito. (ESSLIN, 1978, p. 52-53).

SANTOS, Márcio Silveira dos. Que tragédia é essa? Contextualizando Tragédias Gregas no Ensino de Teatro na EJA. Revista da FUNDARTE. Montenegro, p.01-20, ano 20, oํ 43, outubro/dezembro de 2020.

Disponível em: http://.seer.fundarte.rs.gov.br/index.php/revistadafundarte/index> 20 de dezembro de 2020. 


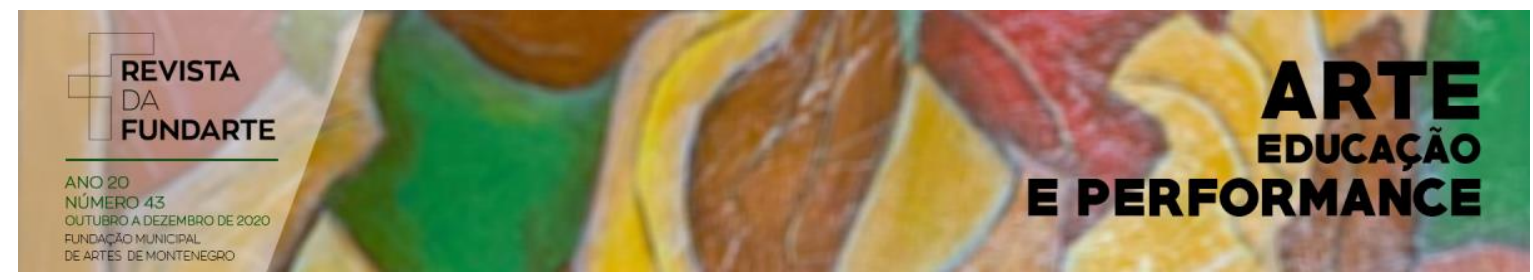

Outro elemento importante da tragédia grega além dos mitos utilizados nas tramas, é a participação do coro, o qual possui uma forma peculiar de explanação dos fatos, anteriores às cenas representadas pelos personagens principais. Então se observa neste detalhe, que o coro retratado nos textos atuais dos alunos, exibe uma postura crítica, muitas vezes representada pela juventude mais radical, que revela 0 mundo das aparências, bem como desvela a hipocrisia das relações e a impossibilidade de uma comunicação efetiva, temas abordados pelo teatro do absurdo e tantos outros estilos teatrais criados no século XX. Outros elementos foram aplicados na criação dramatúrgica e em seguida, também colocados em cena, como a unidade espacial e de andamento;

Pode haver esquemas de intensidades que crescem até um clímax para depois baixar, formas ascendentes de intensificação gradativa de todos os elementos (velocidade, andamento, ritmo de luz, cor) e outras, descendentes, nas quais elas gradativamente se atenuam; ou ainda outras circulares, nas quais o final retorna a configuração inicial. (ESSLIN, 1978, p. 54).

Dentro destes processos de desenvolvimento do enredo de uma peça teatral, o aluno constrói suas tramas e personagens, que mostram o esfacelamento e 0 enfraquecimento do núcleo familiar, abordando alguns tabus sociais. Com essa postura, é possível notar que se faz presente na formação deste aluno dramaturgo, a busca por uma identidade em meio ao contexto de convívio, que expõe, na maioria das vezes, uma tragédia em eminência. É através das identidades dos personagens que se percebe a valorização das ideias dos autores. E neste processo de reflexão do que lê, escreve e encena, que o aluno passa por uma consciência maior no espaço e no tempo de sua própria relação com as pessoas que convive.

\section{Considerações}

As práticas teatrais realizadas em sala de aula pelos alunos e alunas durante as atividades na Educação de Jovens e Adultos, na busca de soluções e saídas para

SANTOS, Márcio Silveira dos. Que tragédia é essa? Contextualizando Tragédias Gregas no Ensino de Teatro na EJA. Revista da FUNDARTE. Montenegro, p.01-20, ano 20, no 43, outubro/dezembro de 2020.

Disponível em: http://.seer.fundarte.rs.gov.br/index.php/revistadafundarte/index> 20 de dezembro de 2020. 


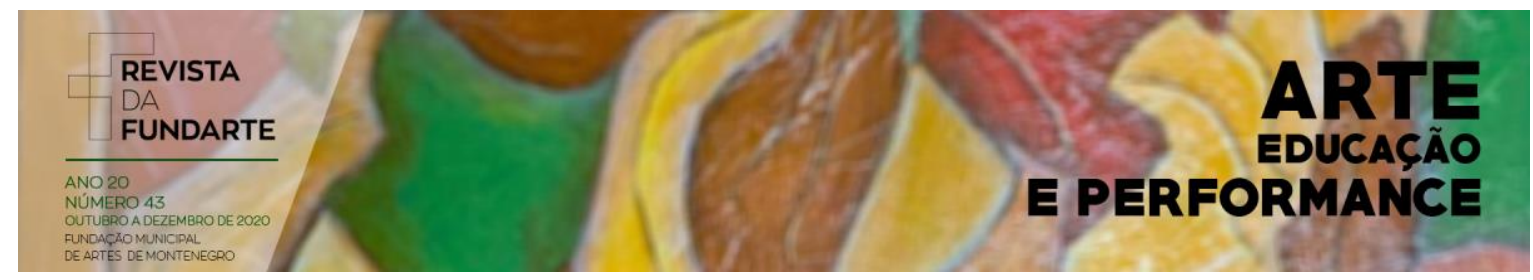

conflitos e crises, levantadas através da contextualização de tragédias gregas, propiciaram uma tomada de postura frente às adversidades, gerando um debate construtivo, calcado na visão crítica-dialética. Durante os encontros das aulas de teatro, constituíram um lugar ao sol, um espaço de reflexão, que em outro momento do cotidiano é difícil obter. São fatores e acontecimentos que comprovam as pequenas transformações ao praticar arte.

O Teatro na Educação de Jovens e Adultos se efetivou como ferramenta de mudanças, veio para somar enquanto linguagem de expressão e liberdade no cumprimento das Diretrizes Curriculares Nacionais. Através de atividades de ensino de teatro houve a legitimação de uma educação transformadora por meio do fazer artístico, com consideráveis resultados de aprendizagem e desenvolvimento da potencialidade criadora do aluno/aluna; vide nossa investigação histórico-crítica, sobre o ensino para além dos muros escolares, sujeito a mudanças, através de propostas em conjunto; constituímos novas histórias, novos caminhos, novas políticas de se fazer cultura na escola e na comunidade, a partir do que o aluno trazia de seu cotidiano e as inquietações deste educador que vos escreve, sempre em estado de alerta para com as notícias do mundo.

Muitas vezes um cidadão vai reclamar em espaços populares e reuniões comunitárias sobre as difíceis e morosas mudanças por parte daqueles que detêm o poder, mas sem uma conscientização maior deste cidadão sobre o seu papel real de construtor de uma sociedade igualitária e democrática, não haverá transformações sociais significativas. Ele necessita, antes, de um aprendizado através do qual possa entender melhor o poder que tem na economia, enquanto consumidor; na cultura como produtor/apreciador de arte; na educação como aluno; na política através do voto, na polícia, na filosofia, no teatro, e outras esferas da sociedade. Acredito, depois desta pesquisa, que todo aluno pode ter sim uma parte deste aprendizado através das experiências com o teatro, seja qual for o bairro, periférico, ou não.

Por fim, destaco que este recorte aqui apresentado, fez parte de um trabalho maior, que, quando no meio do seu desenvolvimento, foi agraciado com o Prêmio

SANTOS, Márcio Silveira dos. Que tragédia é essa? Contextualizando Tragédias Gregas no Ensino de Teatro na EJA. Revista da FUNDARTE. Montenegro, p.01-20, ano 20, no 43, outubro/dezembro de 2020.

Disponível em: http://.seer.fundarte.rs.gov.br/index.php/revistadafundarte/index> 20 de dezembro de 2020. 


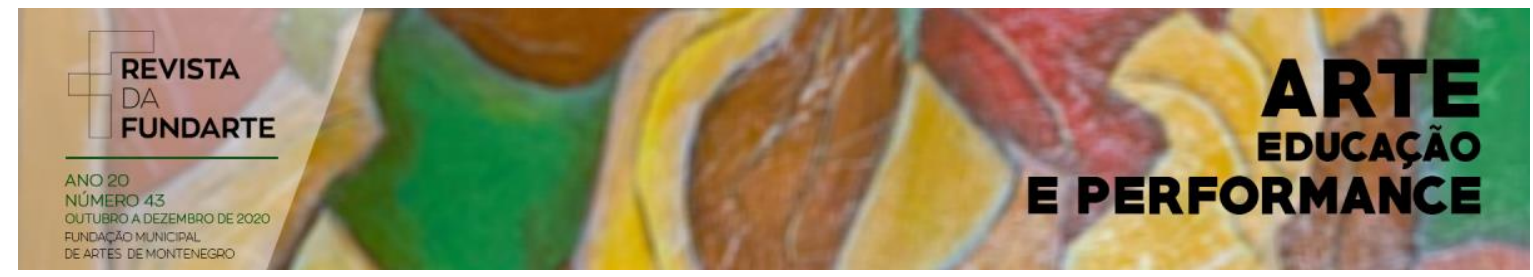

Paulo Freire - Mestre Cidadão, categoria EJA - Educação de Jovens e Adultos. Este Prêmio foi concedido pela Câmara de Vereadores do Município de São Leopoldo, através de uma comissão composta por docentes dos Programas de PósGraduação em Educação das Universidades da região do Vale dos Sinos, para professores que tenham desenvolvido projetos relevantes com resultados significativos em escolas e comunidades.

\section{Referências:}

BENTLEY, Eric. O Dramaturgo como Pensador: um estudo da Dramaturgia nos Tempos Modernos. [tradução Ana Zelma Campos.] Rio de Janeiro: Civilização Brasileira, 1991.

BOAL, Augusto. A Estética do Oprimido. Rio de Janeiro: Garamond/Funarte, 2009.

BOAL, Augusto. O Arco-Íris do Desejo. Rio de Janeiro: Civilização Brasileira, 2002.

BOAL, Augusto. Teatro do Oprimido e outras poéticas políticas. Rio de Janeiro: Civilização Brasileira, 1975.

BOAL, Augusto. Técnicas Latino-Americanas de Teatro Popular. São Paulo: Hucitec, 1979.

BOAL, Augusto. 200 exercício e jogos para o ator e o não ator com vontade de dizer algo através do teatro. Rio de Janeiro: Civilização Brasileira, 1980 a.

BOAL, Augusto. Stop: C'est Magique! Rio de Janeiro: Civilização Brasileira, 1980 b.

BRANDÃO, Junito de Souza. Teatro Grego - Tragédia e Comédia. 3a Edição. Rio de Janeiro: Vozes, 1985.

ESSLIN, Martin. 1978. Uma Anatomia do Drama. [tradução Barbara Heliodora.] Zahar. Rio de Janeiro, 1978.

FREIRE, Paulo. Conscientização: teoria e prática da libertação - uma introdução ao pensamento de Paulo Freire. [tradução de Kátia de Mello e Silva; revisão técnica de Benedito Eliseu Leite Cintra] - 3. Ed.. - São Paulo: Moraes, 1980.

SANTOS, Márcio Silveira dos. Que tragédia é essa? Contextualizando Tragédias Gregas no Ensino de Teatro na EJA. Revista da FUNDARTE. Montenegro, p.01-20, ano 20, no 43, outubro/dezembro de 2020.

Disponível em: http://.seer.fundarte.rs.gov.br/index.php/revistadafundarte/index> 20 de dezembro de 2020. 


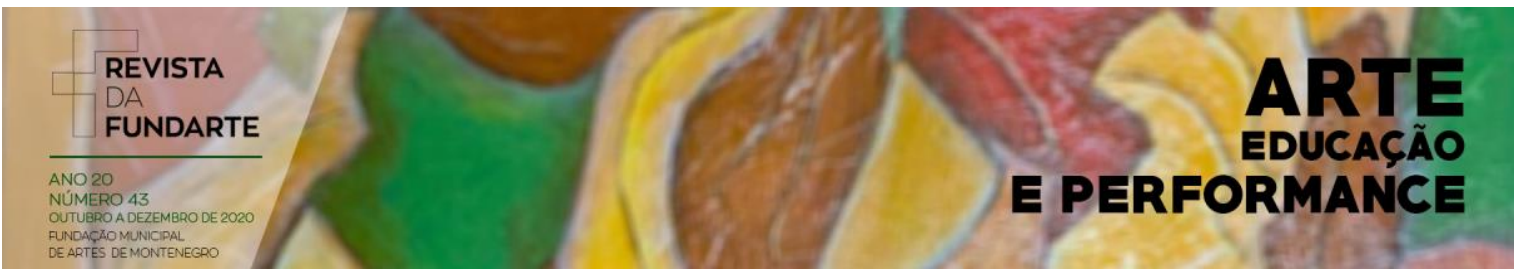

FREIRE, Paulo. Pedagogia da Autonomia - saberes necessários à prática educativa. São Paulo: Paz e Terra, 1996.

FREIRE, Paulo. Política e Educação. São Paulo: Cortez, 1993.

FREIRE, Paulo. Pedagogia do Oprimido. Rio de Janeiro: Paz e Terra, 1970.

GIL, João Pedro Alcântara. A abordagem Dialética na Pesquisa de Teatro e Educação. Revista Cena, ano 3, n³. Porto Alegre: UFRGS, 2004.

Parâmetros Curriculares Nacionais Arte (PCNs ARTE). Brasília: Ministério da Educação e do Desporto Secretaria de Educação Fundamental, 1997.

PAVIS, Patrice. Dicionário de Teatro. 2a edição. [tradução sob a direção de Jacob Guinsburg e Maria Lúcia Pereira.] São Paulo: Perspectiva, 2003.

SÓFOCLES. Édipo Rei / Antígona. [tradução Jean Melville.] São Paulo: Martin Claret, 2003.

VYGOTSKY, Lev Semynovitch. Formação Social da Mente - O Desenvolvimento dos Processos Psicológicos Superiores. [tradução Paulo Bezerra.] São Paulo: Martins Fontes, 2002.

VYGOTSKY, Lev Semynovitch. Pensamento e Linguagem. [tradução Paulo Bezerra.] São Paulo: Martins Fontes, 1987.

\section{Filmes}

Poderosa Afrodite, de Woody Allen. 1995.

Romeu + Julieta, de Baz Lurhmann. 1996.

SANTOS, Márcio Silveira dos. Que tragédia é essa? Contextualizando Tragédias Gregas no Ensino de Teatro na EJA. Revista da FUNDARTE. Montenegro, p.01-20, ano 20, oㅡ 43, outubro/dezembro de 2020.

Disponível em: http://.seer.fundarte.rs.gov.br/index.php/revistadafundarte/index> 20 de dezembro de 2020. 